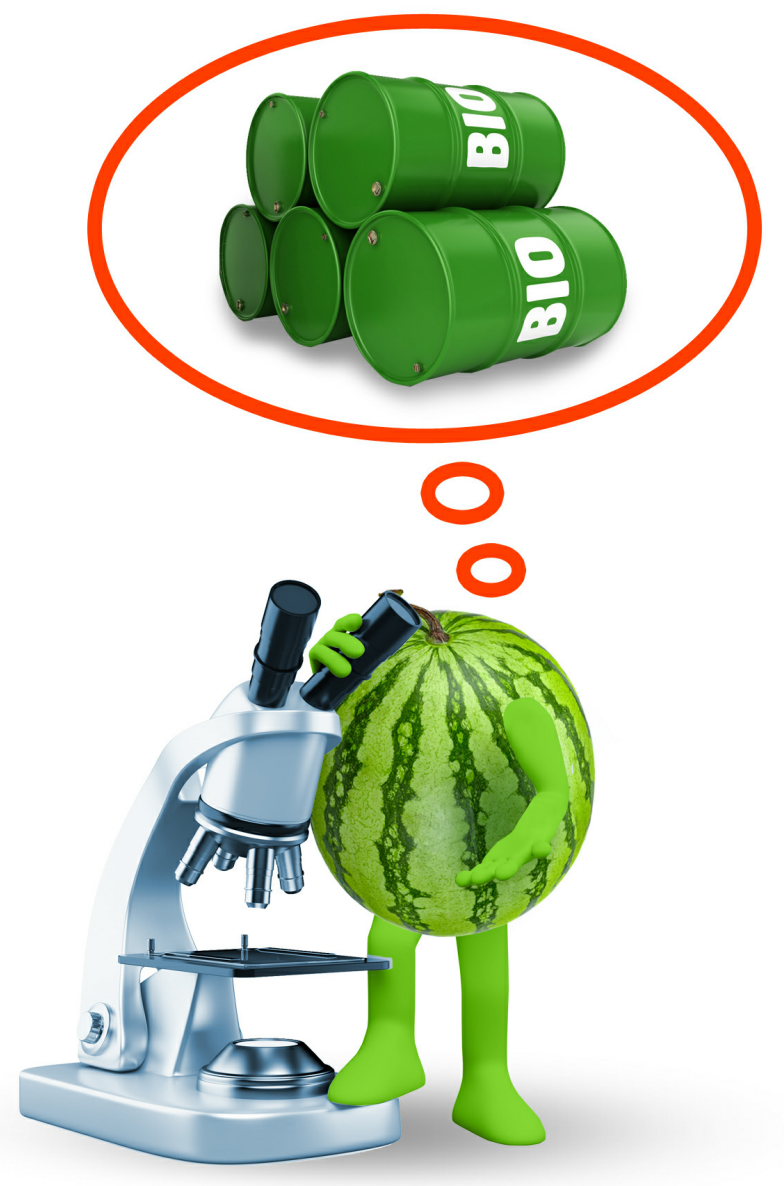

\title{
SCIENCE-BUSINESS RELATIONS IN THE OPINION OF UNIVERSITY EMPLOYEES. EXPECTATIONS VERSUS REALITY
}




\section{S sciendo}

\section{SCIENCE-BUSINESS RELATIONS IN THE OPINION OF UNIVERSITY EMPLOYEES. EXPECTATIONS VERSUS REALITY}

\section{dr hab. Michał Jacuński}

University of Wrocław, Faculty of Social Sciences, Institute of Political Science michal.jacunski@uwr.edu.pl • ORCID 0000-0002-6492-4945

DOI: $10.2478 /$ minib-2019-0012

\section{Summary}

The aim of this article is finding out, based on the obtained empirical data from an opinion poll carried out among the employees of the University of Wrocław, in what way and in what scope cooperation with entrepreneurs (business) takes place on the individual level and on the level of a university. The obtained responses served the purpose of analysis and diagnosis of the level and potential of cooperation between the scientific-didactic personnel, including doctoral students and the economic environment. Key factors stimulating and hampering cooperation were defined. The intermediate goal was to find out, whether in light of the expressed opinions a university is still perceived as a place for carrying out goals typical of a 2nd generation, Humboldt-type university, or whether the features of a creative 3 rd generation ${ }^{1}$ university can be seen. 3rd generation university is focused more on cooperation with the external environment and an exchange of resources. By means of the theory of rational choice two hypotheses were formulated and confirmed: first of all, university employees cooperate with entrepreneurs bypassing the university and the second thing is that cooperation with business is above all a source of individual benefits and is assessed as good. The survey was carried out among the employees of the University of Wrocław in the first half of 2018.

Keywords: university personnel, reform of higher education, science-business relations, intersectoral cooperation 



\section{Introduction}

The problem of appropriate utilization of the potential of human resources of universities in Poland has been discussed for at least a dozen years. Innovativeness, economic and technological development, carrying out R\&D projects, commercialization of research have become the dominant contexts for the situation of deliberations on the models of cooperation of scientific units with the business environment. The tightening of cooperation of intersectoral science and the economy is expected both by national bodies, above all, central bodies of the administration and think tanks, as well as by bodies of the European Union. Solutions and instruments that will encourage scientific units to more intensively work on the acquisition of partners (entrepreneurs) willing to establish cooperation and the other way round entrepreneurs interested in cooperation with the science sector - are sought after. The direction of strategic thinking transposing these expectations to confirmed examples, finds them in the activity of some Polish universities, where technical, exact, natural, or medical areas of scientific knowledge are dominant. At the same time with regard to the functioning of universities with developed areas of humanistic-social knowledge what is particularly visible are problems with determining direct roles that they could play to support economic development and pro-innovative activities. Obviously, it is possible to find positive examples of systemic stimulation of cooperation covering initiatives in the whole country. We can recognize, among others, projects carried out in the financial perspective 2007-2013 under the Operational Programme Human Capital, action 8.2.1. Support for cooperation of the sphere of science and companies (Innovation Portal of the Polish Agency for Enterprise Development) as such positive examples. They covered internships of scientific employees in companies and internships of entrepreneurs at universities. However, these projects contributed much more to stimulating individual strategies of professional development than to support for lasting structural-organizational changes at universities.

The reasons and limitations behind the unsatisfactory condition of both Polish science and readiness for cooperation of universities and the 
economy were highlighted by three teams which in 2016 prepared for the Ministry of Science and Higher Education proposals of assumptions for the so-called bill 2.02. The teams named, among others: lack of diversification of universities' revenues and low share of non-budget funds (Izdebski, 2016), low readiness to accept increasing connections between higher education institutions and their economic environment, which is associated with redefinition of culture, norms and academic values (Kwiek, Antonowicz, Brdulak and others, 2016, p. 77), as well as not taking measures aimed at optimization of intellectual capital and raising its productivity (Radwan, 2016, p.4). Expectations with regard to the reform of science and higher education in Poland concern achieving a state in which universities abandon carrying out goals typical of 2 nd generation universities of the Humboldt type and change into 3rd generation universities. Scientific activity conducted locally (on the national level) and lack of interest in the utilization of generated knowledge is confronted with the necessity of developing creative features and greater focus on cooperation with the external environment and exchange of resources.

The analysis of the results of empirical research carried out on, among others, employees of scientific units, which concerned the experiences from cooperation of science (universities) - business shows that mainly cases from a few voivodeships were described: Lubelskie, Łódzkie, Mazowieckie, Śląskie, Wielkopolskie ${ }^{3}$. The Author of the publication carrying out a query didn't manage to find research covering other regions, including Lower Silesia, which makes it possible to conclude that research conclusions made by the Author provide additional information in the area of discussed issues.

Taking the above into consideration, what was formulated as the main goal of the article is identification and explanation, on the basis of obtained empirical data from an opinion poll conducted among the employees of the University of Wrocław, of the reasons for either taking up, or not taking up cooperation with entrepreneurs (business). The obtained answers also served the purpose of analysis and diagnosis, both on the individual level and the institutional level, the levels and potential of cooperation between scientific-didactic personnel, including doctoral students and the economic environment. 


\section{Conceptualization and operationalization of the research}

Both for theoretical assumptions and for the interpretation of the obtained results the theory of rational choice was used (Coleman, 1994; Becker, 1990). Its main elements boil down to the conclusion that: 1) the main actor making decisions is an individual, 2) individuals make deliberate choices, according to what is best and useful for them, 3) in economic and to some extent social behaviours individuals follow own business based on calculation of costs and benefits.

Based on the theoretical framework, studied literature on the subject and own critical observations, the following hypotheses were formulated:

H1. If employees of the University of Wroctaw decide to cooperate with entrepreneurs, they do it without the participation of the university.

H2. Cooperation with business is associated with individual benefits for employees and is highly appreciated.

Taking into consideration the adopted research goal and the necessity to verify the hypotheses the decision was made to carry out a quantitative research based on the utilization of research techniques and methods from the area of social sciences. An empirical approach will enable the observation of particular features and factographic findings, as well as explanation of the reasons for starting, or not starting cooperation with business by scientific employees.

The acquisition of research material was carried out by means of carrying out two measurements covering the whole population of employees of the University of Wrocław. The plan of the research consisted of a few stages: 1) conceptualization and the creation of a measuring instrume ${ }^{4}$; a survey technique with the application of author's questionnaire, which was available online ${ }^{5}$ (web-based survey method) was used, 2) the implementation of two waves ${ }^{6}$ of direct distribution of an invitation to participate in the questionnaire survey in form of e-mails to all scientificdidactic employees and doctoral students, that is, to a total of 3.547 people from 10 faculties $\left.^{7}, 3\right)$ collecting results and monitoring the correct conduct of the measurement, 4) aggregation, selection and refinement of data.

As a result of carrying out two measurements with the use of a questionnaire survey a close to $11 \%$ of filled questionnaires (that is 385 
questionnaires) were obtained, which is a very good result. From the methodological point of view due care was exercised to make sure that the research process delivers reliable data. Here it is necessary to conclude that the research is not fully representative for the population of university employees due to different size of respondent's quotas representing faculties diversified in a specific way. The data set is non-parametric and at the same time the research sample is not heterogenic both due to age and held academic titles, or membership in organizational units. However, the analysis of obtained answers makes it possible, taking into consideration Author's full awareness of the limitations of the possibility of extrapolating the results to the whole population of employees of the University of Wrocław and other universities in Poland, to apply certain generalizations and draw conclusions on the basis of statistical analyses carried out with support of non-parametric tests and to compare the distribution of frequency of the observed features.

\section{Research results ${ }^{8}$}

In the first part of the questionnaire two filtering questions were applied. Their purpose was to obtain responses only from people who have experience in the area of cooperation with business. The first question was whether an employee has ever received an offer of cooperation and the second question was whether he, or she decided to start such cooperation. During the formulation of questions it was assumed that science-business cooperation, according to W. Dziembała and J. Czyżewska-Misztal (2016, p. 166) involves "various kinds of interactions, direct and indirect, formal and informal, taking place between the sector of companies and the scientificresearch sector bringing mutual benefits (...), taking various forms".

The obtained responses (see Chart 1 and Chart 2) show that about $40 \%$ of employees confirm contacts with business. Are these contacts durable, or occasional in character? The analysis of declared frequency of contacts shows that in this group of respondents last year about $1 / 3$ didn't cooperate with entrepreneurs, while another $1 / 5$ cooperated sporadically, that is, once a year. The remaining respondents constitute a continuously cooperating group, constituting $1 / 5$ of answers and cooperating a few times. 
Chart 1. Have You ever during your work/doctoral studies at the university receive an offer of cooperation from the business community?

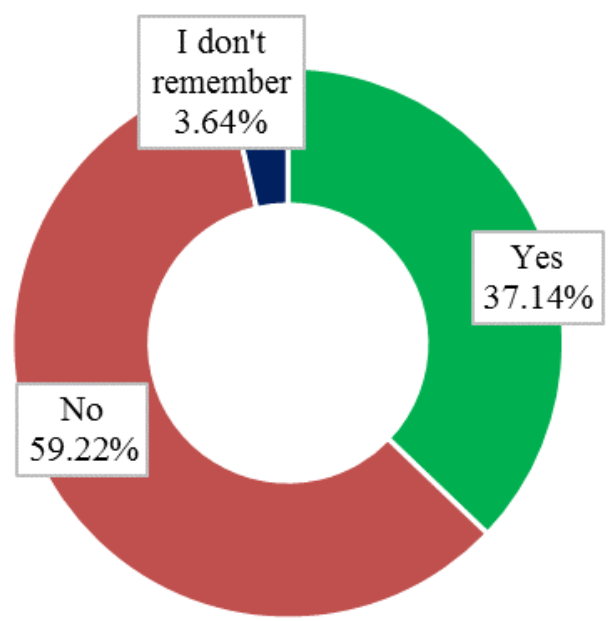

Chart 2. Have You ever during your work/doctoral studies at the University of Wroclaw started cooperation with entrepreneurs?

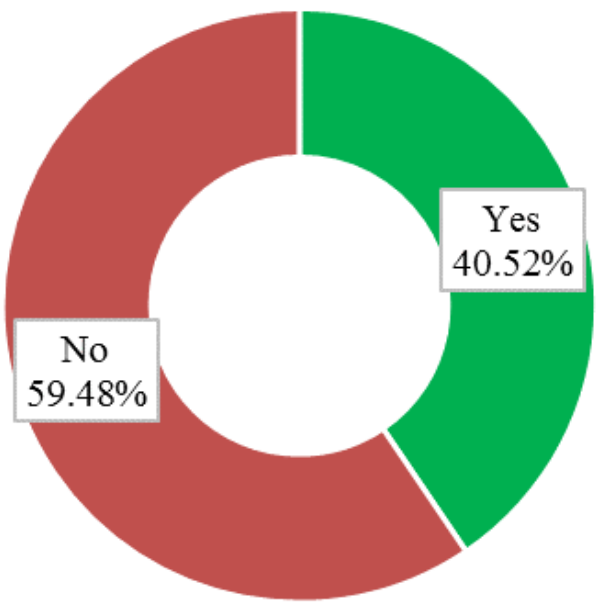

Source: Own materials prepared on the basis of the results of conducted research, $\mathrm{N}=385$.

The circumstances of establishing cooperation clearly point to small participation of own work environment on the level of faculty, or the whole university, as well as scientists' external environment, in which potentially links with business can be established, e.g. in clusters, within the activities of Business Environment Institutions, or government agencies. As data on Chart 3 illustrate, cooperation takes place directly, either through an employee's independent contact with an entrepreneur (the most cases), or an opposite solution, possibly also through a person at the university already cooperating with business. At the same time the conducted cross analysis shows that the awareness of both the functioning business environment institutions and the understanding of the term ${ }^{9}$ itself is at a very low level. Almost a half of respondents skipped this question and merely every tenth respondent admitted that they knew such entities from the area of Wrocław, or Lower Silesia.

Cooperation with entrepreneurs is above all local and regional in character. The respondents primarily pointed to the area of Wrocław, the Wrocław poviat and Lower Silesia as the places of entrepreneurs' origin. About one third pointed to other regions, or cities in Poland. 15\% started 
Chart. 3 Circumstances of establishing cooperation with entrepreneurs (data in \%)

Question: How was contact with entrepreneurs established?

Through independent contact

Company proposed it itself

Through a company at the university already

cooperating with an entrepreneur

In course of a programme financed by EU

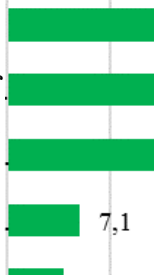

Through the faculty

Through the university

In course of carrying out a programme financed

by domestic funds

Through a business environment institution

Through cooperation within a cluster | 0,8

Through a government agency 0,8

Source: Own materials prepared on the basis of the results of conducted research, $\mathrm{N}=127$.

cooperation with a company from abroad. For economic development in the regional perspective this has serious consequences, as it shows that potential benefits of intersectoral cooperation will be felt on the level of regional centres. This fits in the findings of researchers from Great Britain (Laursen, Reichtein, Salt, 2011) who showed that geographical proximity of universities and businesses has a positive impact on the eagerness and likelihood of starting cooperation.

Respondents who declared that they haven't cooperated with business, were asked to give reasons for not starting cooperation. The main reasons (compare Chart 4) concern lack of associations between scientific specialization and entrepreneurs' needs, which is also associated with not linking such cooperation with the development of professional career, or ordinary lack of need, both bottom-up own need and top-down institutional-organizational need. Every fourth respondent thinks entrepreneurs are responsible for the problem, as they don't express the will to cooperate. Similar reasons were observed in the research ${ }^{10}$ by 
D. Trzmielak (Trzmielak, 2015), who claimed that in case of Poland significant factors limiting the possibility of cooperation are: lack of partners among entrepreneurs, lack of need for cooperation, lack of links between the conducted works and companies' needs.

Chart 4. The reasons for not starting cooperation with the representatives of business (data in \%)

My scientific specialization doesn't respond to the needs of companies

There was no need for that

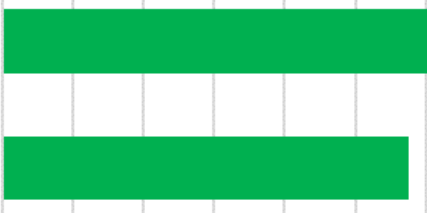

No will to cooperate among the entrepreneurs

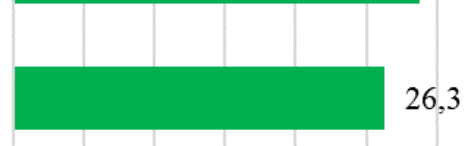

This is not necessary in my professional career

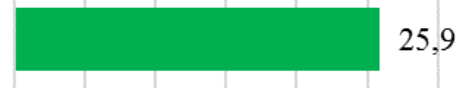

Nobody demanded this from me

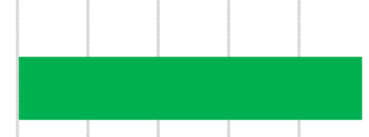

What draws attention during an analysis of the answers given in an open form is that respondents refer to fundamental issues concerning the essence of university on the one hand and on the other hand the determinant of adapting to the logic of the system's operation. What illustrates such approach are the following statements:

"Scientific work at a university is above all cognitive, selfless in character", "Business doesn't need primary research", "This is not necessary in professional career and may even turn out to be harmful devoting time to work on subjects that won't lead to the creation of scientific publications which are the basis for the assessment of an employee". 
At the same time some answers refer to the barriers for cooperation. The barriers named by respondents usually arise from different character of the functioning of science and business: "Different way of thinking among businessmen and scientists", "Recipients usually expect fast, cheap solution to a local problem", "Expecting the effects of cooperation (work) too fast".

According to scientists there is also a problem with the false image of social sciences and humanities: "We keep hearing that social sciences are unfit for cooperation with business", "Underestimating humanists as potential business partners. This image is shaped to a large extent by the mass media, but also by the Ministry of Science and Higher Education".

Internal and external barriers for cooperation in the relationship between science and business, present both among universities and companies are well known in Poland, have been identified and described in numerous scientific sources and popular science sourc ${ }^{11}$. This makes it possible to presume that individual awareness of decision-makers, politicians, experts, scientists, as well as collective awareness of public authority bodies responsible for economic policy, innovation policy, or scientific policy is based on documented sources. In the recent years the occurrence of many factors of systemic, or structural character leading to inertia and the inability to make changes in the area of intersectoral cooperation has been confirmed.

Using the above reasons as a basis for further deliberations, can we notice potential space in which cooperation could be expanded? Respondents were asked to name the level of interest of university's internal and external stakeholders in cooperation with business on a 4-point scale. In light of answers visible on Chart 5, the most promising group are students and doctoral students whose interest is either high, or moderate. At the same time the approach of university authorities and scientific-didactic employees is clearly ambivalent. Here the distribution of answers suggesting interest, low level of interest, or lack thereof is more, or less equal. As a result, the opinions that entrepreneurs and company employees are either not interested, or not interested very much are dominant. 
Chart 5. Stakeholders' interest in cooperation of universities with business, according to the respondents

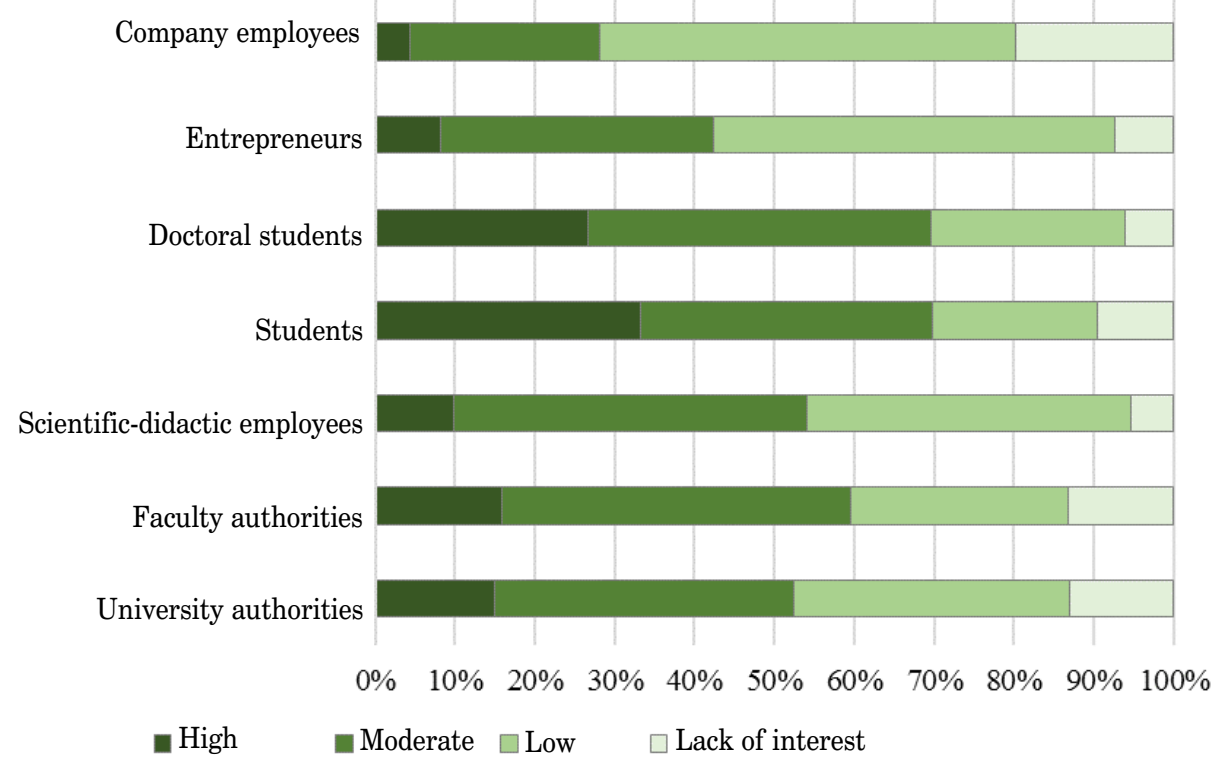

Source: Own materials prepared on the basis of the results of conducted research, $\mathrm{N}=266$.

Surveys ordered by the Ministry of Science and Higher Education, carried out over a decade ago, show that entrepreneurs and scientists regard benefits from cooperation differently . Did the employees of the University of Wrockaw give similar answers? The participants of the survey were asked to mark and arrange in sequence a maximum of three advantages arising from cooperation with business. Possible answers were contained in multiple-choice questions (see Table 1): in the first column the individual benefits for the employee and indirectly institutional benefits for the university were taken into consideration; in the second column the possible benefits for business were contained and in the third column answers relating to direct advantages for the university were contained.

Top positions among answers concerning benefits for the employee point clearly to satisfying basic needs, that is, obtaining additional income and the possibility of acquiring practical skills, as well as verification of "theory in practice", that is, confronting your own scientific-didactic activity with the needs of the environment. The problem of insufficient financing for science, including low level of salaries, is confirmed by the respondents' answers. 
What contributes the most to cooperation with business is impoverishment of employees and the need to look for additional sources of income. The advantages that could contribute to scientific progress, e.g. to the development and transfer of technology, or the implementation of $R \& D$ projects placed at lower position.

What is the perception of potential benefits for business? The respondents notice the praxeological dimension of business activity and entrepreneurs' rationality of acting, as what they see as the first benefit is the possibility of solving a particular problem. High position of responses concerning the transfer of knowledge seems to be a confirmation of the perception of the university as a place where knowledge is gathered and later - through employees - transferred out of the university. This definitely fits in the traditional understanding of the role of 2nd generation universities. Among the less popular responses there were the development of employees' competences, raising competitiveness, growth of innovativeness. A problem in case of many contests for financing of R\&D activity is low interest resulting from, among others, low level of networking of the contacts of scientific units with entrepreneurs, which is confirmed by the fact that merely $8.7 \%$ of responses affirmed the benefits for business arising from participation in contests.

The respondents were also asked to mark the benefits for the university, which can arise from cooperation with business. The question was given to all respondents, without filtering people who have experiences from cooperation with business. The following five main benefits were named: additional possibilities of developing employees, adapting the teaching programmes to the needs of the labour market, organization of internships and trainings for students, transfer of knowledge and support for the commercialization of research results. Distant positions were occupied by responses concerning long-term benefits related to organic growth, such as building entrepreneurial, pro-innovative attitudes. Also, the possibility of transferring knowledge wasn't appreciated much.

In further, final part of the article the areas of cooperation of university employees with entrepreneurs will be discussed (see Table 2 and Chart 6). The diagnosis of potential areas was based on four, natural pillars of activity: 1) teaching, 2) organization, 3) research, 4) development. We can assume that from the perspective of internal conditions in particular scientific units, their profile of activity limits the possibility of cooperation in all areas. In particular with regard to non-technical universities, areas 1 and 2 may dominate over 3 and 4 . 
Table 1. Expected benefits arising from cooperation with business, according to employees (data in \% of responses)

\begin{tabular}{|c|c|c|c|c|c|}
\hline \multicolumn{2}{|l|}{$\begin{array}{l}\text { Individual benefits } \\
\text { (for the employee) }\end{array}$} & \multicolumn{2}{|l|}{$\begin{array}{l}\text { Benefits for } \\
\text { business }\end{array}$} & \multicolumn{2}{|l|}{$\begin{array}{l}\text { Benefits for } \\
\text { the university }\end{array}$} \\
\hline Additional remuneration & 70.1 & $\begin{array}{l}\text { Solving a particular } \\
\text { problem }\end{array}$ & 51.2 & $\begin{array}{l}\text { Additional possibilities of } \\
\text { development for } \\
\text { scientific-didactic employees }\end{array}$ & 45.9 \\
\hline Gaining practical skills & 55.1 & $\begin{array}{l}\text { Transfer of knowledge from } \\
\text { university to business }\end{array}$ & 42.5 & $\begin{array}{l}\text { Adaptation of teaching } \\
\text { programmes at university } \\
\text { to the needs of the labour market }\end{array}$ & 45.5 \\
\hline $\begin{array}{l}\text { Verification of the usefulness } \\
\text { of conducted scientific-didactic } \\
\text { activity in practice }\end{array}$ & 37.0 & $\begin{array}{l}\text { Development of employees' } \\
\text { professional competences }\end{array}$ & 26.0 & $\begin{array}{l}\text { Organization of internships } \\
\text { and trainings } \\
\text { Possibility of transferring }\end{array}$ & 42.9 \\
\hline Personal development & 32.3 & $\begin{array}{l}\text { Raising the competitiveness } \\
\text { of a company }\end{array}$ & 25.2 & $\begin{array}{l}\text { Possibility of transferring } \\
\text { for students }\end{array}$ & 39.5 \\
\hline $\begin{array}{l}\text { Broadening mental } \\
\text { horizons }\end{array}$ & 19.7 & Growth of innovativeness & 20.5 & $\begin{array}{l}\text { Support for the } \\
\text { commercialization } \\
\text { of scientific-research works }\end{array}$ & 30.5 \\
\hline $\begin{array}{l}\text { Possibility of transferring } \\
\text { knowledge }\end{array}$ & 18.9 & Development of new services & 18.1 & $\begin{array}{l}\text { Improving the quality of } \\
\text { education at the university }\end{array}$ & 30.1 \\
\hline $\begin{array}{l}\text { Acquiring additional } \\
\text { financing for projects }\end{array}$ & 12.6 & Developing new products & 17.3 & $\begin{array}{l}\text { Growth of prestige of a } \\
\text { university/scientific unit }\end{array}$ & 29.7 \\
\hline $\begin{array}{l}\text { Establishing cooperation during } \\
\text { the implementation of } R \& D\end{array}$ & 10.2 & $\begin{array}{l}\text { Developing employees' } \\
\text { soft competences }\end{array}$ & 16.5 & $\begin{array}{l}\text { Promoting the university } \\
\text { in business community }\end{array}$ & 28.6 \\
\hline $\begin{array}{l}\text { projects } \\
\text { Possibility of transferring } \\
\text { technology }\end{array}$ & 2.4 & $\begin{array}{l}\text { Facilitating access to the } \\
\text { results of } \\
\text { scientific-research works }\end{array}$ & 13.4 & $\begin{array}{l}\text { Promotion of the university's } \\
\text { scientific achievements } \\
\text { in the business community }\end{array}$ & 25.6 \\
\hline & & $\begin{array}{l}\text { Participation in contests for } \\
\text { financing R\&D works }\end{array}$ & 8.7 & $\begin{array}{l}\text { Possibility of establishing } \\
\text { contacts in various } \\
\text { branches }\end{array}$ & 24.8 \\
\hline & & & & $\begin{array}{l}\text { Establishing cooperation in } \\
\text { course of implementation } \\
\text { of R\&D projects }\end{array}$ & 24.8 \\
\hline & & & & $\begin{array}{l}\text { Building pro-innovative } \\
\text { attitudes }\end{array}$ & 18.1 \\
\hline & & & & $\begin{array}{l}\text { Building entrepreneurial } \\
\text { attitudes }\end{array}$ & 17.7 \\
\hline & & & & $\begin{array}{l}\text { Possibility of transferring } \\
\text { technology }\end{array}$ & 16.9 \\
\hline & & & & $\begin{array}{l}\text { Promotion of academic } \\
\text { entrepreneurship }\end{array}$ & 10.9 \\
\hline
\end{tabular}

Source: Own materials prepared on the basis of the results of conducted research, $N=127$ (answers concerning individual benefits and benefits for business), $\mathrm{N}=266$ (answers in column of benefits for the university). 
Table 2. Potential areas of cooperation of university employees with entrepreneurs and chosen activities that can be carried out in cooperation with entrepreneurs

\begin{tabular}{|c|c|}
\hline 1. TEACHING & 2. ORGANIZATION \\
\hline $\begin{array}{l}\text { Organizing trainings/workshops } \\
\text { Didactics (participation in courses, consulting } \\
\text { the contents of teaching programmes etc.) } \\
\text { Transfer of knowledge } \\
\text { Promoting the culture of entrepreneurship }\end{array}$ & $\begin{array}{l}\text { Organization of internships and trainings } \\
\text { Organization of conferences and meetin } \\
\text { Creating clusters } \\
\text { Animation of contacts } \\
\text { Business incubation and pre-incubation }\end{array}$ \\
\hline 3. RESEARCH & 4. DEVELOPMENT \\
\hline $\begin{array}{l}\text { Preparing an expertise } \\
\text { Scientific-technical consulting } \\
\text { Transfer of technology } \\
\text { Carrying out scholarship and research programmes } \\
\text { Organizing the financing of research }\end{array}$ & $\begin{array}{l}\text { Commercialization of research results } \\
\text { Improving a product/service } \\
\text { Marketing/market research } \\
\text { Patent registration and protection of intellectual } \\
\text { property rights } \\
\text { Business consulting } \\
\text { Implementation of a new product } \\
\text { Profiling the personnel, appropriate recruitment policy } \\
\text { New clients, or new products }\end{array}$ \\
\hline
\end{tabular}

Source: Own elaboration.

The analysis of obtained answers makes it possible to conclude that among the respondents a few activities of expert-consulting character are dominant. Further activities are related to organization. The percentage of answers taking into consideration joint ventures related to development, or research is low. Expert opinions, consulting, or broadly understood transfer of knowledge don't have to be connected to typical research-focused, innovative activity, or conducting scientific research and subsequent commercialization of results. Taking into consideration the fact that according to the respondents' declarations cooperation with business takes place outside the institutional frameworks of universities, mainly on the basis of established individual contacts, the named areas of cooperation confirm this phenomenon. According to researchers who analyzed cooperation of companies and universities in the region of Mazovia (Poznańska et al., 2012), typically innovative and researchfocused projects require a systemic approach. Meanwhile, as other research projects concerning academic centres show (Emerling, Orlińska, Węsierska, 2010), the most popular forms of cooperation include isolated actions characterized by lack of continuity of cooperation. The sequence and preference of particular answers among the surveyed employees of the University of Wrocław still fit in this way of maintaining relations with business. 
Chart 6. Areas of cooperation of employees with entrepreneurs (data in \%)

Conducting trainings/workshops

Preparing an expertise

Scientific-technical consulting

Didactics (participation in courses, consultation of curriculum content)

Transfer of knowledge

Improving a product/service

Organizing of internships and apprenticeships

Organizing conferences and meetings

Marketing/market research

Business consulting

Implementation of a new product

Obtaining financing for activities carried out at the university.

Commercialization of research results

Acquisition of financing for actions at the university.

Participation in audit/carrying out an audit

Transfer of technology

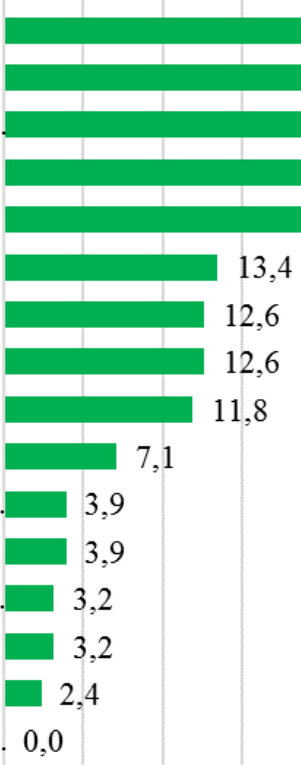

Patent registration and protection of property rights 0,0

Source: Own materials prepared on the basis of the results of conducted research, $\mathrm{N}=127$.

What is the best form that developing science-business relations can take at a university? The preferred forms of cooperation with business, which generally prove successful, or will prove successful at a university are, according to about a half of respondents, professional internships and trainings as well as expert consultations. Every third respondent thinks that these are R\&D projects, scholarship programmes and specialist courses. The least popular responses related to the organization of conferences and seminars.

\section{Summary}

Testing the hypotheses based on the analysis of given responses, we should conclude that: 
1) Hypothesis H1. If the employees of the University of Wrocław start cooperation with entrepreneurs they do it without the participation of the university has been confirmed, as most respondents who declared that they cooperate with business, confirm that they establish contacts outside the framework of institutional cooperation through, among others, independent contacts with an entrepreneur or the other way round, possibly, through other employees who know an entrepreneur. Employees' strong capacity for adaptation doesn't put the university in the position of a necessary agent. If employees notice strong interest in the business-science relations, they point more to faculty authorities than to university authorities. Can we identify the reasons for this state of affairs? The answer is complex. There are objective and subjective factors behind the existing situation, as pointed out by the respondents. Among objective factors of endogenous nature we can name bureaucratization of cooperation at a university. Among exogenous, but subjective factors, there is the lack of interest in cooperation among companies, undervalued role of cooperation between the communities and legal barriers. A barrier named by over a half of respondents is also weak flow of information between the communities.

What additionally supports the confirmation of the hypothesis is the fact that respondents are strongly convinced that they have knowledge that could be useful for entrepreneurs (64\% agree with this statement) and that they conduct research which could be useful for the business community (47\%). At the same time there is very weak conviction that at the university there are institutional solutions which facilitate establishing cooperation with business. If at their university, or more broadly, within the higher education system there are no advantageous mechanisms, according to the theory of rational choice, individuals take independent measures giving them particular benefits.

2) Hypothesis H2. Cooperation with business is associated with individual benefits for employees and is highly appreciated has also been confirmed, as among the main reasons for starting cooperation the employees named achieving financial goals, personal development, gaining practical skills and at the same time the related verification of the usefulness of conducted scientific-didactic activity. Employees naturally see various secondary benefits for the university, but they 
strive above all to achieve their own goals. Secondary benefits for universities are focused, according to the respondents, mainly on the process of education and to a smaller extent on the commercialization of research, or implementation of $R \& D$ projects.

Almost three quarters of respondents cooperating with business assessed their experiences as good, or very good. Thus, it is possible to presume that the current state of affairs is fine for employees and the prospects for top-down initiation of mechanisms of cooperation with business are negative due to the already formed habits.

Unfortunately, the conducted questionnaire survey still to only a small extent can help answer the question, whether the level of cooperation existing at universities justifies the claim that scientific knowledge created with a framework of connections - university - employees - entrepreneurs (Lisowska, Ropęga, 2015) is transformed into solutions, in particular, innovative solutions, which are later transferred to the economy. Despite this, what seems to be an important observation is that in $41 \%$ of declared cases of cooperation the results of research works were used, which means that despite the lack of a framework of cooperation with business under the supervision of the university and despite the highly unlikely unawareness of respondents the results generated by employees at universities indirectly affect the business practices and the development of companies.

The analysis of answers suggests that intersectoral cooperation may bring benefits mainly in the professional development of employees, but also in the process of teaching and organization of internships and trainings and thus for students. Meanwhile, the university as an institution is not perceived as a primary beneficiary, or organizer of cooperation. Low culture of entrepreneurship and low capacity of the university for institutional organization of relations with the economic environment fits in the - as experts from Allerhand Institute have observed (Radwan, 2016) - distance between the scope of necessary changes addressing the needs of the state, national economy and above all global quality standards in science and the ability to adapt and implement these changes, which it is hard to reduce.

In the national scientific community the discussed challenges ahead of the contemporary university form a long list. Among the most important ones there are: redefinition of, or loyalty to the central mission, the 
functioning of a dual network of research universities and non-universities, e.g. equivalents of higher vocational schools, specialization of education versus maintaining general education, coping with the processes of globalization, especially with competitive pressure and parametrization, ability to create innovations, link research to the economy, etc.

Every university should estimate in the first place what resources it currently has, which allow carrying out basic activities, concerning the process of education and organizational aspects on the basis of cooperation with external stakeholders, including entrepreneurs. Second thing is that it is necessary, if changes in higher education are supposed to lead to higher efficiency of Polish science, to investigate the previous activity associated with research and development, conducted in cooperation with business, for the purpose of defining the role that a university is supposed to play with regard to employees, or whole research teams. Universities with highly developed humanist-social profiles, which have ambitions to achieve the status of a research university should even more focus on defining the framework for cooperation with the environment, as it may be a source of significant stimuli, leading to the growth of scientific perfection, stepping outside the proverbial "ivory tower", or better orientation in the reality of the changing world.

The case, confirmed by the findings of this research, when the pragmatic approach of employees who organize their relations with the economic environment wins, recalls sociologists' assessments from the beginning of Polish systemic transformation in the 1990's (GizaPoleszczuk, Marody and Rychard, 1999; Wnuk - Lipiński, 2005). The necessity to adapt to new social-political-economic conditions and reality was a collection of various remedial techniques, which revolved around highly developed social and situational resourcefulness. Is this feature, a specific path of self-reliance, going to dominate also the future of Polish universities?

\section{References}

\footnotetext{
1 The models are explained by e.g. K. B. Matusiak (2011). Podstawowe cechy poszczególnych modeli (różnych generacji) uniwersytetu in a group publication edited by himself, titled Innowacje i transfer technologii - Stownik pojęć. Warszawa: Polska Agencja Rozwoju Przedsiębiorczości, p. 313.
} 
2 The new Act on higher education and science, which came into force on October 1, 2018, was called by its authors, or co-authors Act 2.0 .

${ }^{3}$ Compare the detailed description of research with, among others: Lisowska, R., Ropęga, J. (2015). Współpraca sfery nauki i biznesu z perspektywy funkcjonowania ośrodków akademickich. In: P. Głodek, M. Wiśniewska (red.) Budowa potencjatu uczelni wyższej do wspótpracy z przedsiębiorstwami. Rola scoutingu wiedzy. Łódź: Wydawnictwo Uniwersytetu Łódzkiego, p. 123-140, Dziembała, M., Czyżewska-Misztal, D. (2016). Wspieranie współpracy nauki i biznesu w polskich regionach na przykładzie województwa śląskiego i wielkopolskiego. In: M. Kosała, M. Urbaniec, A. Żur (ed.). Współczesne dylematy badań nad przedsiębiorczością. Przedsiębiorczość Międzynarodowa vol. 2, $\mathrm{nr}$ 1. Kraków: Uniwersytet Ekonomiczny w Krakowie, p. 165-185, Gola, A., Kaniewska-Pawik, I., Świć, A. (2015). Analiza poziomu współpracy w obszarze nauka-biznes na przykładzie pracowników naukowo-dydaktycznych Politechniki Lubelskiej. In: Innowacje w zarzadzaniu i inżynierii produkcji, vol 2. Lublin: Politechnika Lubelska, Katedra Organizacji Przedsiębiorstwa; Instytut Technologicznych Systemów Produkcyjnych.

${ }^{4}$ What served as an instrument were survey questionnaires available online. Its structure was dominated by closed questions in some cases expanded with open questions. Rankings, half-open multiple-choice questions, as well as scales, which put the respondents in a situation in which they had to make a choice, were used.

5 The questionnaire was available in the period 12-29.03.2018 at www. surveymonkey.com/r/ankietaWNS.

6 Two waves were carried out 2 weeks apart in March 2018.

${ }^{7}$ A total of 385 people took part in the survey. Almost $90 \%$ of answers came from independent and nonindependent scientific-didactic employees.

8 The research project was carried out in 2017-2018 in cooperation with Dolnośląską Agencją Współpracy Gospodarczej sp. z 0.o. as a result of the implementation of the project titled „Szkoleniowa sieć wiedzy i praktyki” - udoskonalenie oferty wyspecjalizowanych usług doradczo-szkoleniowych dla sektora mikro, małych i średnich przedsiębiorstw (MMŚP) w oparciu o współpracę nauki i biznesu within the framework of the City Programme of Support for Higher Education and Science and the Sector of Business Activity organized by the Commune of Wrocław.

${ }^{9}$ Based on the answer "I don't know what such institutions do" to the question Do You know business environment institutions operating in Wrocław, or Lower Silesia?

10 A survey carried out in 2013-2014 by D. Trzmielak in Poland and selected European and North-American countries. Source: D. Trzmielak (2015). Science and business cooperation. Barriers in Poland within the context of selected European and North American countries, Marketing of Scientific and Research Organisations, MINIB, 2015, Vol. 18, Issue 4, DOI: 10.14611/minib.18.04.2015.14, p. 160.

${ }^{11}$ Compare with, among others Davey, T., Galán-Muros, V., Meerman, A., Kusio, T. (2013). The state of university-business cooperation in Poland. Brussels: Science-to-Business Marketing Research Centre, UG and University Industry Innovation Network (UIIN), http://www.ub-cooperation.eu/pdf/poland.pdf, viewed 3.11.2018, Gajewska, Kurowska-Pysz (2012), Relacje nauka-biznes: wybrane czynniki kształtujące współpracę uczelni wyższych i przedsiębiorstw. Logistyka 5/2012, p.; 56-62, Sokół A., Wptyw barier na zakres wspótpracy przedsiębiorstw ze sferą $B+R$ $i$ ich implikacje dla rozwoju innowacji w Polsce, http://www.instytut.info/Vkonf/site/33.pdf, viewed 13.10.2018; S. Pangsy-Kania (ed.) Wiedza i innowacje rozwoju polskich regionów sity motoryczne i bariery. Fundacja Rozwoju Uniwersytetu Gdańskiego \& Instytut Wiedzy i Innowacji, Gdańsk 2007; Bryła P., Możliwości współpracy polskich uczelni wyższych ze sferą biznesu. Studia Edukacyjne, 31, 2014; Cyran K., Bariery współpracy sfery biznesu z jednostkami naukowymi z perspektywy małych i średnich przedsiębiorstw. Modern Management Review, MMR, vol. XX, 23-33, 2015.

12 A research project ordered by the Ministry of Science and Higher Education. The results of this research have been mentioned in the publication Bromski, K. (ed.) (2013). Wspótpraca nauki i biznesu. Doświadczenia $i$ dobre praktyki wybranych projektów w ramach Programu Operacyjnego Innowacyjna Gospodarka na lata 2007-2013. Warszawa: PARP. https://www.parp.gov.pl/files/74/81/626/18863.pdf, viewed 30.10.2018 


\section{Bibliography}

1. Becker, G. (1990). Ekonomiczna teoria zachowań ludzkich. Warszawa: PWN.

2. Bromski, K. (ed.) (2013). Wspótpraca nauki i biznesu. Doświadczenia i dobre praktyki wybranych projektów w ramach Programu Operacyjnego Innowacyjna Gospodarka na lata 2007-2013. Warszawa: Polska Agencja Rozwoju Przedsiębiorczości, https://www.parp.gov.pl/files/74/81/626/18863.pdf (viewed 30.10.2018).

3. Bryła, P. (2014), Możliwości współpracy polskich uczelni wyższych ze sferą biznesu. Studia Edukacyjne, 31/2014, 95-112.

4. Coleman, J. (1994). Foundations of Social Theory. Cambridge: Harvard University Press.

5. Cyran, K. (2015). Bariery współpracy sfery biznesu z jednostkami naukowymi z perspektywy małych i średnich przedsiębiorstw. Modern Management Review, MMR, vol. XX, 23-33.

6. Davey, T., Galán-Muros, V., Meerman, A., Kusio, T. (2013). The state of university-business cooperation in Poland. Brussels: Science-to-Business Marketing Research Centre, UG and University

7. Industry Innovation Network (UIIN), http://www.ub-cooperation.eu/pdf/poland.pdf, (viewed 3.11.2018).

8. Dziembała, M., Czyżewska-Misztal, D. (2016). Wspieranie współpracy nauki i biznesu w polskich regionach na przykładzie województwa śląskiego i wielkopolskiego. W: M. Kosała, M. Urbaniec, A. Żur (ed.). Współczesne dylematy badań nad przedsiębiorczością. Przedsiębiorczość Międzynarodowa, vol. 2, No 1. Kraków: Uniwersytet Ekonomiczny w Krakowie, p. 165-185.

9. Emerling, A., Orlińska, A., Węsierska, S. (2010). Wspótpraca firm z sektorem edukacji. Raport $z$ badania. Warszawa: Fundacja Aurea Mediocritas.

10. Gabryś, A. (ed.) (2008). Najlepsze praktyki w zakresie wspótpracy ośrodków naukowych i biznesu przy wykorzystaniu środków z UE. Warszawa: Fundacja Aurea Mediocritas.

11. Gajewska P., Kurowska-Pysz, J. (2012). Relacje nauka-biznes: wybrane czynniki kształtujące współpracę uczelni wyższych i przedsiębiorstw. Logistyka 5/2012, 56-62.

12. Giza-Poleszczuk, A., Marody, M., Rychard, A. (1999). Strategie Polaków wobec zmiany systemowej. In: J. Kurczewska (ed.). Zmiana spoteczna. Teorie i doświadczenia polskie. Warszawa: IFiS PAN.

13. Gola, A., Kaniewska-Pawik, I., Świć, A. (2015). Analiza poziomu współpracy w obszarze nauka-biznes na przykładzie pracowników naukowo-dydaktycznych Politechniki Lubelskiej. W: Innowacje w zarzadzaniu i inżynierii produkcji, vol. 2. Lublin: Politechnika Lubelska, Katedra Organizacji Przedsiębiorstwa; Instytut Technologicznych Systemów Produkcyjnych.

14. Izdebski, H. (2016). Ustawa 2.0 - Zatożenia systemu szkolnictwa wyższego. https://www.swps.pl/warszawa/wydzial-prawa/projekt-ustawa-2-0 (viewed 31.10.2018).

15. Kwiek, M., Antonowicz, D., Brdulak, J, Hulicka, M., Jędrzejewski, T., Kowalski, R., Kulczycki, E., Szadkowski, K., Szot, A., Wolszczak-Derlacz, J. (2016). Projekt zatożeń do ustawy Prawo o szkolnictwie wyższym. Poznań: Uniwersytet im. Adama Mickiewicza. http://cpp.amu.edu.pl/wp-content/uploads/2016/11/Projekt_zalozen_Kwiek_et_al_2016_Final.pdf (viewed. 31.10.2018). 
16. Laursen, K., Reichtein K. T., Salt T. (2011). Exploring the Effect of Geographical Proximity and University Quality on University-Industry Collaboration in the United Kingdom. Regional Studies, vol. 45 no. 4, p. 507-523.

17. Lisowska, R., Ropęga, J. (2015). Współpraca sfery nauki i biznesu z perspektywy funkcjonowania ośrodków akademickich. W: P. Głodek, M. Wiśniewska (red.) Budowa potencjału uczelni wyższej do wspótpracy z przedsiębiorstwami. Rola scoutingu wiedzy. Łódź: Wydawnictwo Uniwersytetu Łódzkiego, p. 123-140.

18. Matusiak, K. B. (2011). Podstawowe cechy poszczególnych modeli (różnych generacji) uniwersytetu. In: K. B. Matusiak (red.) Innowacje i transfer technologii - Stownik pojęć. Warszawa: Polska Agencja Rozwoju Przedsiębiorczości.

19. Pangsy-Kania, S. (ed.) (2007). Wiedza i innowacje rozwoju polskich regionów sity motoryczne i bariery. Gdańsk: Fundacja Rozwoju Uniwersytetu Gdańskiego \& Instytut Wiedzy i Innowacji.

20. Portal Innowacji, Polska Agencja Rozwoju Przedsiębiorczości, http://www.pi.gov.pl/Finanse/chapter_94602.asp (viewed 4.11.2018).

21. Radwan, A. (2016). Ustawa 2.0, Prezentacja koncepcji Instytutu Allerhanda. 22. http://ustawa20.allerhand.pl/wp-content/uploads/2016/09/ustawa20-IA.pdf (viewed . 31.10.2018).

22. Sokół, A. (2009). Wptyw barier na zakres wspótpracy przedsiębiorstw ze sfera $B+R$ i ich implikacje dla rozwoju innowacji $w$ Polsce, http://www.instytut.info/Vkonf/site/33.pdf (viewed 13.10.2018).

23. Trzmielak, D. (2015). Science and business cooperation. Barriers in Poland within the context of selected European and North American countries, Marketing of Scientific and Research Organisations, MINIB, 2015, Vol. 18, Issue 4, DOI: 10.14611/minib. 18.04.2015.14

24. Wnuk-Lipiński, E. (2005). Socjologia życia publicznego. Warszawa: Scholar.

dr inż. Michał Jacuński - assistant professor at the Institute of Political Science of the University of Wrocław. For about a dozen years he has been dealing with both practical and theoretical aspects of the communication of people, political and non-profit organizations, as well as public institutions and companies. He edited and co-created the scientific magazine titled "Central European Journal of Communication". He gave lectures as guest at foreign universities in, among others, Belgium, Spain, Germany, Russia, Hungary. He took part in scientific internships in companies. An expert of the National Centre for Research and Development in the project contests under Smart Growth Operational Programme 2014-2020. 